\title{
Harmonizing Ethnic Claims in Africa: A PROPOSAL FOR ETHNIC-BASEd FEDERALISM $M$ wangi S. Kimenyi
}

M ost African states are unitary with political power vested in the central government. L aws and decisions concerning the public sector are enacted and enforced by the central government. ${ }^{1}$ Authority is delegated to junior government officials who implement policies within rigid guidelines. Provincial and district levels of government serve administrative roles but do not make laws, collect taxes, or make spending decisions. ${ }^{2}$ Strictly speaking, political power is centrally concentrated with heads of states holding the power over all public policies affecting the polity. In most African states, no constitutional limitations constrain the central authority in its exercise of power over public activities at all levels.

The unitary states of Africa largely reflect the colonial legacy. E uropean colonial powers subdivided the African continent among themselves, establishing boundaries that arbitrarily linked heterogeneous

Cato Journal, Vol. 18, No. 1 (Spring/Summer 1998). Copyright $\odot$ Cato Institute. All rights reserved.

$M$ wangi S. Kimenyi is Associate Professor of E conomics at the U niversity of Connecticut and Senior Research Associate of the African Research Institute for Public Policy and $M$ arket Process. He would like to thank an anonymous referee for helpful comments. $\mathrm{He}$ also gratefully acknowledges the support of the E arhart F oundation.

${ }^{1}$ Cameroon, Nigeria, and South Africa have federal systems of government. Those states, nevertheless, have been characterized by a high concentration of decisionmaking authority. In Cameroon and $\mathrm{N}$ igeria, dictatorial governments have not maintained the federal principle. Until recently, South Africa excluded a large number of its population from participating in the political process.

${ }^{2} \mathrm{~L}$ ocal governments in Africa do make some decisions, primarily those that deal with the provision of local public goods. N onetheless, the powers of local governments are very limited, and in most cases the local governments are under the strict supervision of a government ministry. Thus, local governments are independent only to a rather limited degree. Their lawmaking powers are minimal. In fact, the central government can dissolve a local government at will. That was the case in Kenya during the 1980s when the $\mathrm{N}$ airobi City Council, composed of elected councilors, was dissolved and replaced by a City Commission whose members were appointed by the central government. 
groups in one country and separated otherwise homogeneous, or closely related populations, in another. After independence, charismatic leaders, frequently those who had led the nations during the struggles for independence, forcefully argued for unitary governments much like the colonial governments they replaced. Concentration of power was considered a necessary condition to maintain unity. In fact, even decentralization within unitary states has been considered a political risk because it could reinforce tribal loyalty at the expense of loyalty to the nation.

$\mathrm{N}$ onetheless, the presumed benefits of unitary governments have proved illusionary. In virtually all the countries, post independence has been marked by internal strife, military coups, and civil wars. Conflicts have generally been between heterogeneous population groups within the country. Thus, although an argument for establishing centralized unitary states was that such institutional arrangements would help unify the various ethnic groups, the African experience with unitary states has been disappointing. The experiment with unitary states shows that such institutional arrangements are not suited to harmonize the interests of heterogeneous groups.

A common explanation for the institutional crisis in Africa is the extreme poverty in that continent. In other words, poverty is seen as the main cause of institutional crisis rather the outcome of institutional failure. $\mathrm{H}$ owever, research using public choice theory provides alternative explanations for political instability, for unwholesome features of political institutions such as bureaucratic corruption, and for dismal economic performance in Africa. ${ }^{3}$ Those studies treat tribal groups as special interests that compete for transfers from the central government. Members of a particular tribe consider themselves different from those of other groups and have an interest in increasing the welfare of their members relative to that of other tribes. Because of the concentration of power in unitary states, the leadership can redistribute resources from some tribes to others. Consequently, a tendency exists for tribal groups to compete for the control of the instruments of transfer because such control assures the controlling group a consistent flow of transfers. Tribal competition for control of the instruments of transfer has had disastrous results in many African countries. The ongoing conflicts in R wanda, Sudan, and Zaire are but a few of the cases where members of one tribe continue to inflict serious atrocities against members of other groups. The competition for political control results in tribal conflicts, military coups, and civil 
wars. Such outcomes, plus the nonoptimal public policies designed to benefit some groups at the expense of others, translate into poor economic performance. It is therefore difficult to justify the claim that unitary states unite heterogeneous populations.

There is convincing evidence showing that Africa's unitary states do not comprise "optimal units of collective choice." Unifying ethnic groups by decree has resulted in institutions that are not suited to achieving cooperative agreements among the various groups. I nstead, more often than not, unitary states associate with Pareto-inferior outcomes whereby competing groups fail to achieve cooperative solutions in prisoner's dilemma situations. G roups in these institutions are therefore trapped in Pareto-inferior noncooperative outcomes. Thus, in essence, highly centralized unitary states have resulted in outcomes that are very much like those found in stateless societies described by Thomas H obbes ([1651] 1962). It is clear that the observed crises in Africa reflect institutional failures, and for Africans to emerge from this state of affairs, it will be necessary to establish institutions that facilitate the achievement of cooperative solutions in prisoner's dilemma situations.

This paper advances the idea that the most pressing institutional problems confronting Africans have to do with the internal organization of their states. Specifically, African countries do not use political arrangements that are suited to solving prisoner's dilemma problems. The paper argues that to harmonize conflicting interests of various ethnic groups, countries characterized by high degrees of ethnic diversity should adopt institutional arrangements that utilize ethnic units as a basis for local governments. The analysis presented here suggests that because members of each ethnic group consider themselves different from members of other groups, establishment of ethnic government units that possess a fair degree of autonomy would be the most desirable form of organizing African societies. Since ethnic groups associate with particular territories, African states are naturally suited for the establishment of federal systems of government. ${ }^{4}$

The paper proceeds as follows: First a brief history of African countries and their institutions is discussed. E thnicity and its implications for the organization of African societies are then examined. E thnic groups are viewed as being analogous to voluntary clubs that perform some desirable functions for the members. It is demonstrated that ethnic groups may be best suited to provide some "local" public

${ }^{4}$ In some countries, different ethnic groups live in the same regions and no group can claim exclusive ownership rights. The case of $\mathrm{H}$ utu and Tutsi in Burundi and $\mathrm{R}$ wanda is a good example of a country where two rival groups share territory. 
goods and therefore ethnicity could be used to define local jurisdictions in a federal system. The paper then outlines some features of African institutions that make federalism desirable followed by some concluding remarks.

\section{Colonial Rule and the Creation of the African State}

Institutions of collective choice emerge as solutions to minimize transaction costs of achieving cooperative agreements. Such agreements are necessary for Pareto optimality in presence of public goods and externalities. Absent a government, the independent self-interested actions of each member of society translate into outcomes that are Pareto-inferior. This result is demonstrated by the classic prisoner's dilemma matrix as shown in Table 1. The matrix shows the payoffs to two tribal groups who are in a conflict situation. Tribe members can either live peacefully or steal from each other. The payoff matrix shows that both tribal groups are better off if they live peacefully (cell \#1) instead of stealing from one another (cell \#4). H owever, each tribal group would be better off if it succeeded in stealing from the other (cell \#2 and \#3) as long as the other decided to live peacefully. The situation shown in the matrix represents a dilemma because the "steal" strategy dominates the "live peacefully" strategy. In absence of cooperative agreements, the tribal groups are worse off than if they entered into such agreements. Once the tribal groups recognize this dilemma, it is in their best interest to reach agreement and achieve the cooperative solution (cell \#1). ${ }^{5}$

\begin{tabular}{|c|c|c|}
\hline \multicolumn{3}{|c|}{$\begin{array}{c}\text { TABLE } 1 \\
\text { TRIBAL GROUP'S DILEMMA }\end{array}$} \\
\hline Group 1 & \multicolumn{2}{|c|}{ Group 2} \\
\hline & $\begin{array}{l}\text { Live } \\
\text { Peacefully }\end{array}$ & Steal \\
\hline $\begin{array}{l}\text { Live } \\
\text { Peacefully }\end{array}$ & $\begin{array}{c}\# 1 \\
(300,300)\end{array}$ & $\begin{array}{c}\# 3 \\
(0,400)\end{array}$ \\
\hline Steal & $\begin{array}{c}\# 2 \\
(400,0)\end{array}$ & $\begin{array}{c}\# 4 \\
(30,30)\end{array}$ \\
\hline
\end{tabular}


As noted, African countries are characterized by dictatorial political systems, serious internal divisions, and civil wars. Those outcomes suggest that institutional arrangements in Africa are not effective in solving prisoner's dilemma problems and are unable to facilitate the achievement of cooperative solutions. While many countries are attempting to establish constitutional democracies, there seems to be little hope that such efforts will result in a resolution to the current crisis in that continent. To understand why institutional arrangements in Africa fail to facilitate the achievement of cooperative agreements, and why merely writing new constitutions without radical transformation of the institutions may be futile, it is necessary to look at the origin of the present day African states and their institutional arrangements.

The emergence of the modern African state is largely the result of a number of events that disrupted the traditional African way of life. The most important of these include the African slave trade, the spread of Islam, and the imposition of colonial rule. The people of $\mathrm{N}$ orth Africa, for example, readily accepted I slam and governmental institutions introduced by Arabs. I slam also had some influence on people living along the East African Coast. The slave trade on the other hand provided a lucrative source of wealth to Arabs, E uropeans, and African Kingdoms that were involved in the trade. The slave trade also created a variety of conflict situations as slave raids spread from the coast to the interior regions of Africa and guns were introduced into African states as payment for slaves. Those events disrupted the organization of traditional societies but did not have significant lasting effects on the basic institutions of most of sub-Saharan Africa.

Probably the most important event that explains contemporary African institutions is E uropean colonialism. D uring the late 1800 s, G reat B ritain, F rance, Germany, B elgium, and to a lesser extent I taly and Spain, were heavily engaged in attempts to place under their control parts of the African continent- what is known as the "scramble for Africa." B etween 1870 and 1880, the E uropean powers rapidly expanded their territorial claims and as each power acquired more and more of the continent, it became apparent that competition for Africa threatened peace in Europe. In 1884, Chancellor Otto Von $B$ ismarck of Prussia invited $E$ uropean nations for a conference in B erlin with the main goal of regularizing the scramble for Africa. The Berlin Act of February 26, 1885, stipulated how Africa would be partitioned into European colonies. By 1910, the partition of Africa was achieved and, for the next 45 years, only Liberia and Ethiopia (which was occupied briefly by I taly) remained independent nations (Burke 1991). 
Colonial rule adversely affected African institutions. Indeed, many of the problematic features of current African political institutions are the product of the colonial experience (M baku and Kimenyi 1995). ${ }^{6}$ $M$ ost important, in partitioning Africa among themselves across spheres of influence, colonial powers rarely took into consideration the issue of ethnic heterogeneity. In some countries, the boundaries were drawn in a manner that separated members of the same ethnic group by placing them in different countries while at the same time placing other, formerly separate groups in the same country. Partition was implemented without due regard to ethnicity, culture, or even the existing institutions of government. The various groups did not participate in deciding which other groups to unite with nor did they have an opportunity to agree on the nature of their relationship with these other groups. In the process, different ethnic groups were placed within the same authority and confined within the same boundaries. In other cases, members of one tribe were dispersed among different nations. Likewise, colonial partition disrupted long established kingdoms and tribal governments, and also disrupted existing trade networks and other inter-ethnic linkages. Thus, the political units that were created by E uropeans were not only arbitrary but also lacked any strong unifying factors. ${ }^{7}$

At the time of independence, the new nations had to make crucial decisions concerning the constitutional dimensions of government activities. These dimensions included such characteristics as the number of jurisdictional levels, whether the political system was to be unitary with power concentrated at one level, or federal system with power distributed between regional governments and a central government. In the case of the federal system, decisions had to be made concerning the number of levels, such as provincial, district, municipal, and local, and al so the functions that would be performed at each level. Other decisions pertained to procedures and processes of selecting representatives, and the constitutional rules regulating the amendment of the constitution.

In selecting particular constitutional dimensions, the primary objectives included the achievement of both economic growth and a just and free society that provided freedom from oppression of one group by another. The leaders, at least ostensibly, sought to adopt constitutions that would advance individual liberty. 
Concerned by the fact that the various tribal, religious, and linguistic groups in each of the countries considered themselves different from other groups in various respects, the issue of unity was a primary concern. Specifically, unifying the groups into one national state was considered crucial for political stability. To be sure, Africans had to deal with pressing problems of unity after independence that may have required them to adopt unifying policies. For example, many tribal communities existed independently. These communities frequently consisted of thousands of members and possessed well-developed cultures and languages and clear tribal consciousness.

$\mathrm{H}$ owever, the existing national boundaries cut across those groups ignoring the boundaries that defined previously autonomous units. F or this reason, leaders advocated the establishment of unitary states with a high concentration of power. It was claimed that centralizing power allowed for the adoption of uniform policies and for the balancing of economic resources, thus uniting diverse populations.

Some leaders argued that single-party political systems were more appropriate for African countries because all groups (tribal, religious, linguistic), regardless of their differences, would be joined together under one party. Thus, the single-party system was seen as an important unifying agent of otherwise different groups. The leaders warned that unity would be sacrificed if political party competition were to be introduced because different political parties would be dominated by particular tribal and linguistic groups, which in essence would promote tribalism (Winchester 1986). Thus, the common response to diversity was the adoption of policies and institutional arrangements that unified heterogeneous populations by limiting expressions of group preferences. $^{8}$

U nfortunately, attempts to unify ethnic groups in Africa have largely been unsuccessful as evidenced by various ethnic rivalries that have resulted in continuous civil wars in the continent and the domination of some ethnic groups by others. Thus, evidence points to the fact that institutions of the sub-Saharan African countries are not adequate to deal with the high degree of population heterogeneity. Institutional arrangements that have sought to unify ethnic groups by denying them autonomy have not been successful in achieving cooperative agreements among the ethnic groups. These arrangements create situations whereby ethnic groups are trapped in a Pareto-inferior "steal-steal" strategy. It appears that units of collective choice that

${ }^{8} \mathrm{U}$ ntil the recent democratization movements in Africa that took hold during the late $1980 \mathrm{~s}$, most states outlawed political party competition. Even in those that permitted entry of other parties into the political markets, the party activities were largely restricted. 
seek to unify various ethnic groups are not optimal and therefore do not minimize the transactions costs of achieving cooperative agreements. It is contended here that for units of collective choice to minimize the costs of arriving at cooperative agreements, they must to some degree be based on ethnicity.

\section{E thnic Clubs and U nits of Collective Choice}

To appreciate the significance of ethnicity in the organization of African societies, it helps to note a number of features relating to ethnic composition of those countries. The first of these is that subSaharan Africa is ethnically very complex. In total, there are over 2,000 distinct tribes or ethnic societies, each of which has its own language or dialect, culture, and tradition (Ayittey 1992). These tribes vary in size, with some having as few as 100,000 members and others encompassing millions of people. The degree of ethnic heterogeneity varies widely across the countries. In R wanda and Burundi, for example, there are only two primary ethnic groups and two languages. In Sudan on the other hand, there are over 170 distinct languages. In $\mathrm{N}$ igeria, there are between 200 and 400 distinct linguistic groups, and in Zaire, there are about 250 ethnic groups.

The other notable feature is that Africans show a high degree of tribal identification. By and large, identifying with one's tribe is highly valued. As such, resources are devoted to make certain that members of a group continue to identify with that group. In virtually all African communities, children are taught from a very young age that they should identify and be proud of their tribe. Thus, children learn at early ages that it is honorable to vote for members of their tribe or region, and that members of some tribes are not trustworthy and thus they should not do business with them. In some cases, tribe members are warned against associating with members of particular tribes. ${ }^{9}$ As stated by H orowitz (1985, p. 7), "in general, ethnic identity is strongly felt, behavior based on ethnicity is normatively sanctioned, and ethnicity is often accompanied by hostility toward outgroups."

In most areas of everyday life, there are many instances in which individuals identify with members of their own tribe. Thus, even in major cities where people from different tribes live in close proximity, tribal groupings emerge as individuals freely select with whom to associate. Even today, the majority of urban social welfare organizations are organized along tribal lines. U rban soccer leagues are primarily organized along ethnic lines. Strong tribal preference has also been

${ }^{9} \mathrm{~F}$ or example, it is not uncommon to find strong opposition to intertribal marriages. 
revealed in a variety of studies that seek to measure the social or political spatial "distance" between ethnic groups. W. J. B reytenbach (1976: 313), for example, observed that in Zambia, ethnicity played an important role in all types of associations:

\begin{abstract}
$M$ embers of various tribes clustered together on account of their regional and cultural affinities, for instance, western and eastern tribes formed separate clusters due to their particularistic bonds and interests. Those results suggested that ethnic factors played significant roles in formation of voluntary associations among heterogeneous groups, and voluntary associations normally tend to be specifically organized for the pursuit of special interests, be they economic or political, etc.
\end{abstract}

Likewise, Kenneth Little (1957) has observed that tribal-oriented associations - such as the I bo State U nion, which consisted of village and clan groups- rated among the most important voluntary associations in West Africa. I dentifying with one's tribe also dominates in participation in political parties, labor unions, and so on.

The other important feature of African societies in regard to ethnic groups is that in most cases, each group associates with a particular territory. Although the boundaries that demarcate ethnic territories are not always clearly specified, they do nevertheless exist and to a large extent they are respected by the respective groups that live next to each other. ${ }^{10}$ Thus the various ethnic groups have what they refer to as their territory and, in many respects, members of other ethnic groups are considered as outsiders. Thus, by and large, ethnic units do make up what could be called "ethnic nations."

It is well known that the most preferred choices are realized when an individual decisionmaker has maximum independence. In the real world, however, individuals have to associate with others for particular matters. The more people involved in the decisionmaking process, the less likely that an individual's preferred choice will be selected. $W$ ith more and more heterogeneous preferences, the outcomes differ markedly from each person's preferred choice. Because tribes are composed of people who, as a result of their past experiences, family ties, and aspirations, have preferences that are closely related on a variety of matters, decisions that are made by the tribal units are likely to be more representative of individual preferences than would result when many tribes are involved. Thus, tribal organizational units are

${ }^{10}$ Some of the ethnic conflicts that have continued for many years are frequently due to disputes concerning the ethnic territorial boundaries. In other words, they are the result of "poorly" defined ethnic property rights. In most cases, however, the "ethnic" property rights are well defined. 
in some respects analogous to voluntary clubs that are composed of people whose preferences are fairly similar.

The efficiency results of voluntary organizations such as clubs are well known and have been discussed extensively in the economic literature. James Buchanan (1965) was among the first to explore the efficiency properties of voluntary clubs. The economic model of clubs presented by Buchanan assumes a situation where individuals have identical tastes for both public and private goods. The optimal size of a club is determined by the marginal benefits and marginal costs. Figure 1 shows the marginal benefit (MB) and marginal cost (MC) from an additional member as seen by other members. The marginal benefit represents costs savings from adding new members because fixed costs are spread among more people. Additional benefits decline as club size increases. On the other hand, marginal costs increase as club size increases. The rising marginal costs reflect increasing costs due to congestion. The optimal club size $\left(N^{*}\right)$ is one where the marginal benefit club members receive from adding another member equals the additional costs associated with the new member.

Central to the efficient results of voluntary clubs are conditions of entry and exit. A member of a club who does not like a particular club's policies is free to exit and to join clubs that better represent his or her preferences. Although such exit involves costs, individuals make decisions by comparing the benefits of exit with the costs. If
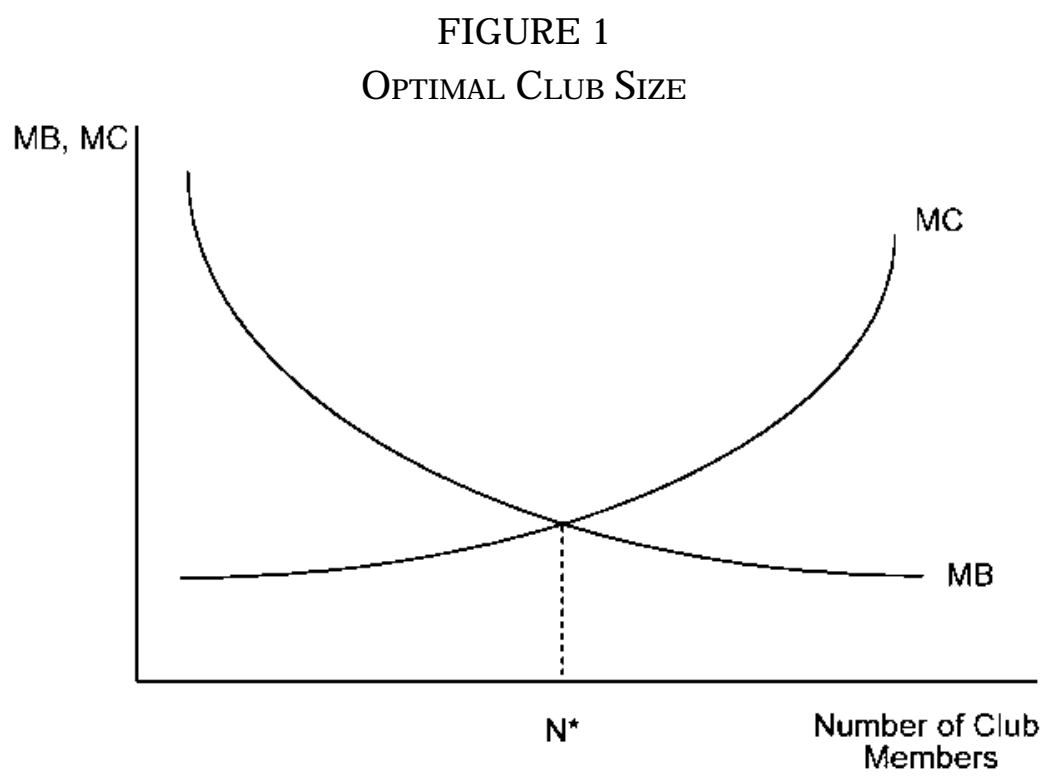
expected benefits exceed the costs of exit, then the individual exits. It is this mobility property of voluntary organizations that guarantees that an individual's preferences are served even in a group setting. The freedom to select those organizations that best serve one's preferences suggests that voluntary clubs and organizations advance individual liberty.

What about the tribe? U nlike voluntary organizations, entry into a particular tribe, other than the one into which a person is born, is not possible. Likewise, exit from one's tribe is practically impossible. While limits to entry and exit may appear to undermine efficiency, I suggest that "partial" exit and "partial" entry are possible and serve the same goals that entry and exit serve in voluntary organizations.

Individuals can select the degree to which they identify with a particular tribe. This opportunity of selective identification allows persons the liberty to associate with members of their tribe on some matters and to disassociate from members of their tribe on other matters and instead to associate with members of other tribes. Thus, on the one hand, the tribe can be viewed as an involuntary association because of entry and exit barriers. On the other hand, identifying with a tribe is voluntary because one can choose the degree to which one identifies with one's own or any other tribe.

The fact that we observe strong tribal identification in Africa should be considered a largely voluntary choice by the individuals concerned. From an economic perspective, the expected benefits of identifying with one's tribal group exceed the costs of such identification. ${ }^{11}$ When members of a tribe live and organize their activities without interfering with members of other tribes, then the tribal unit is an optimal form of organizing for the purpose of providing some goods and services to its members. In this respect, the tribal unit is analogous to a private club that serves the interests of its members.

Jennifer Roback (1991) notes that one of the beneficial tasks performed by ethnic groups is that of assisting the teaching and enforcement of social norms and behavior. Given the prisoner's dilemma situations that face individuals in making collective choices, individual members of society have an incentive to cheat because such behavior

\footnotetext{
${ }^{11}$ Kimenyi (1997b) presents a model of tribal identification that shows how voluntary integration arises. In this model, the demand for identifying with one's tribe is shown by a downward sloping marginal benefit curve while the supply is an upward marginal cost curve of tribal identification. In other words, as individuals identify more and more with members of their tribe, additional benefits fall and additional costs rise. The intersection of the marginal benefit and marginal cost of tribal identification determines the activities that ethnic groups should keep to themselves and the matters that they should organize with members of other tribes.
} 
is profitable. H owever, if everybody cheats on every occasion on which they expect to profit, then everybody in society faces the worst possible outcome. B ecause people have a long-term attachment to their groups (for example, through blood or past memories), they are more likely to have continuous dealings with members of their ethnic group than with members of other ethnic groups. Continuous dealing reduces cheating in prisoner's dilemma situations and as a result ethnic groups may be more efficient in the provision of public goods than the state. Roback (1991: 63) observes:

\begin{abstract}
E thnic attachments can provide significant substitute for contract law. That is, members of ethnic groups that have substantial continuous dealings with each other can develop norms of cooperation, promise-keeping and honesty.... Thus ethnic groups can provide alternatives to government in the provision of certain public goods such as the enforcement of social norms, and in the solution of prisoner's dilemma problems. In fact, ethnic groups and other groups smaller than the modern state may actually be more efficient providers of these kinds of goods.
\end{abstract}

Benefits to members also arise from the tribal organization of production of goods and services. A tribe may possess its own production technology and its own unique division of labor. M embers of the tribe learn different types of production skills and work habits. Thus, in addition to the production of valuable social norms, the tribal organizational unit plays a significant part in organizing the production of goods and services. E thnic groups also provide other services such as social insurance and entertainment and act as sources of collegiality and pride (Congleton 1992).

The club model discussed above is extended to show why organizing along tribal lines may be efficient. If members of the same ethnic group organize particular activities such as the provision of local public goods, then the optimal ethnic club size would be at the point where $M B=M C$, as shown in F igure 1 . The assumption is that members of ethnic groups have fairly close, though not identical, tastes.

Inclusion of members from other ethnic groups affects the optimal size of ethnic clubs in two ways. The first of these is that adding members from other tribes creates a kink in the marginal cost curve (F igure 2). The cost rises because of difficulties in communicating across ethnic and linguistic boundaries. The second result of adding members from other ethnic groups is to create a kink in the marginal benefit curve at the boundary of the ethnic group (Figure 3 ). This reflects the discontinuity in the group norms, which do not extend beyond the group ( $L$ anda 1994). 
Harmonizing Ethic Claims in Africa

\section{FIGURE 2}

Optimal Ethnic Club Size: Kinked Marginal Cost

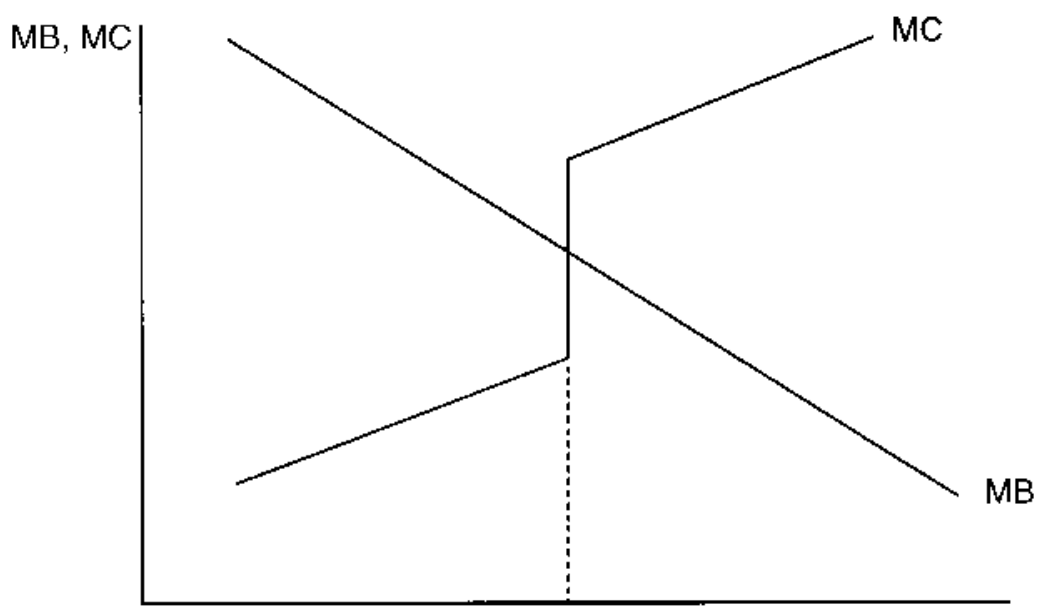

Members of Same

Ethnic Groups
Members of Other

Ethnic Groups

\section{FIGURE 3}

Optimal Ethnic Club Size: Kinked Marginal Benefit

$\mathrm{MB}, \mathrm{MC}$

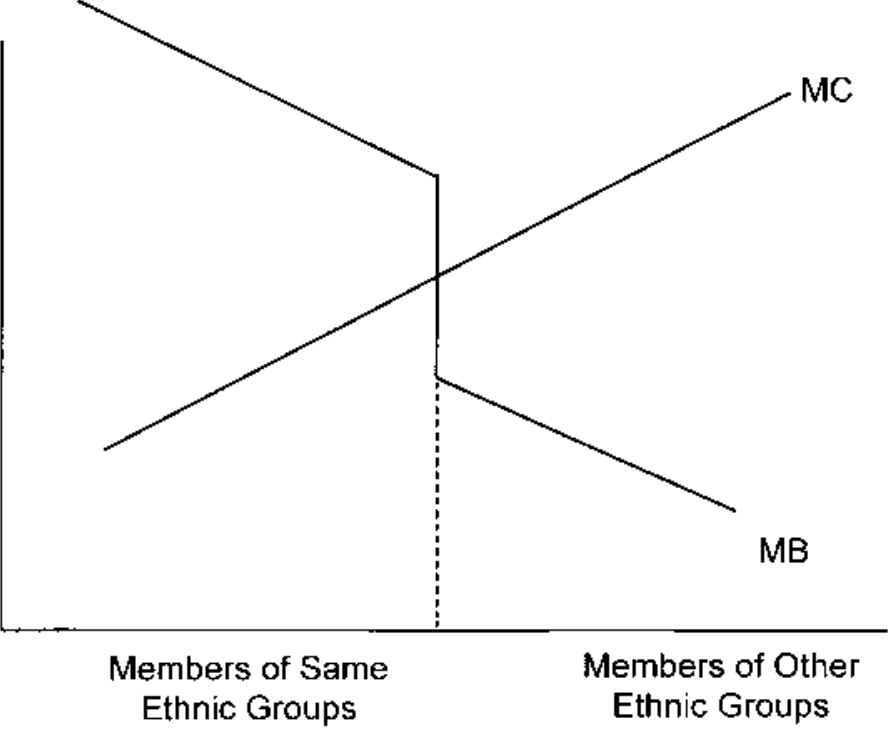


Because of discontinuities in marginal benefit and marginal costs that result from adding members from other ethnic groups, the boundary of the club is marked off by members of one's own ethnic group. ${ }^{12}$ Given that African tribes associate with clearly identifiable territorial boundaries (what is referred to as geoethnicity), then ethnic groups do form a natural basis for defining units of collective choice. Such ethnic units of collective choice are better suited to provide some local public goods. Because of the fact that members of the same ethnic group are engaged in continuous dealings, ethnic-based governments would be better at solving prisoner's dilemma problems. This then suggests that ethnicity must be taken into account in determining the optimal local jurisdictions.

So far, tribal units have been considered analogous to voluntary clubs that are compatible with efficient outcomes. H owever, even voluntary clubs have problems in enforcing compliance. $M$ ancur OIson (1965) has attacked the orthodox view that voluntary associations are al ways efficient in the provision of collective goods and has specifically challenged the view that the effective participation in voluntary associations is virtually universal. Because voluntary associations organize around collective goals, it is often not rational for an individual member to pay for such a goal. Instead, members may pursue their interests by free-riding on other peoples' efforts.

We therefore expect ethnic-based provision of collective goods and services to be undermined by free-riding. As such, members cannot be expected to pay their share voluntarily without some form of organized authority to enforce compliance. Because widespread freeriding lowers the well-being of all members of the ethnic group, everybody benefits when an ethnic government is established. N otice that such a government is analogous to a club management team that enforces payments of fees and dues and oversees that club rules are followed. The free-rider problem is likely to be less prevalent when the group is made up of one ethnic group than when several ethnic groups are involved. ${ }^{13}$

\footnotetext{
${ }^{12}$ We could envision marginal benefits and marginal costs when families, extended families, and clans organize some activities. The marginal benefit and marginal cost curves would have kinks as one moves from organizing activities from family to extended family. L ikewise, including members of other clans would be marked by kinks in the benefit and cost curves. This shows why some activities are best left to the family, extended family, or clan and not the entire tribe. This may explain the rivalry of clans in Somalia.

${ }^{13} \mathrm{~A}$ proposal for the establishment of ethnic governments may be considered radical. $\mathrm{H}$ owever, evidence from the history of African societies shows that such ethnic-based governmental units functioned quite well and had many features of representative governments. See for example, Ayittey (1991), M air (1965), and Vaughan (1986).
} 
Some ethnic groups may be so large that even an ethnic government may not be efficient in preventing free-riding. I $\mathrm{n}$ this case, the population exceeds the optimal club size. Organizing around such an ethnic group is not efficient and in such cases it may be necessary to set up a number of competing governmental units that can monitor freeriding more efficiently. In addition to minimizing free-rider problems, such competing governments open up opportunities for "voting with the feet" because members have several choices of tribal jurisdictions.

E thnic tribal units have other limitations that relate to their sizes. E thnic units may be too large for organizing some activities. Some goods and services require smaller political units. For example, provision of primary school education could be more efficiently organized by the village. Just as, in some cases, individuals organize along tribal lines, at other times they may organize into villages. As a matter of fact, the history of African communities reveals an elaborate division of activities not only by ethnic units, but also by villages and clans.

E thnic units could also be too small to organize for the provision of some goods and services. F or example, it is unlikely that ethnic groups can efficiently organize for the provision of university education. In such cases, it is necessary for different ethnic units to form political associations for the purposes of accomplishing these tasks. $\mathrm{N}$ otice, however, that such associations take the form of market exchange-they are voluntary and thus benefit ethnic groups that enter into such associations. It is also the case that the rules that establish the relationships between such ethnic groups must be reached by agreement. Beneficial political associations will tend to be durable while those that do not benefit all the groups involved will tend to be unstable. The key then is that any form of integration should be by consent. ${ }^{14}$

The discussion above leads us to a similar conclusion to that reached by W. A. Lewis (1965) over three decades ago who noted that the new African governments' attempts to suppress tribal loyalties was a futile exercise. L ewis (p. 68) instead suggested the use of such loyalties as a base for establishing institutions that permitted self-expression by all tribes:

Any idea that one can make different peoples into a nation by suppressing the religious or tribal or regional or other affiliations to which they themselves attach the highest political significance is simply a nonstarter. N ational loyalty cannot immediately supplant

${ }^{14}$ This is similar to the analysis advanced by Buchanan and Tullock (1962) of mutually beneficial political exchange. 
tribal loyalty; it has to be built on top of tribal loyalty by creating a system in which all the tribes feel that there is room for selfexpression.

The primary argument advanced here is that African governments' refusal to permit ethnic groups to organize for the provision of public goods and services has resulted in the creation of units of collective choice that are not suited to achieving cooperative agreements. There are numerous advantages in relying upon the "tribe" as a basis for organizing governments in Africa. F or one, tribal territories provide natural boundaries that can define stable political jurisdictions. In addition, there are various factors that unite members of a tribe that facilitate solving prisoner's dilemma problems such that cooperative outcomes are achieved. Consequently, there is a strong case for defining boundaries of local units along ethnic lines. F or such units to be efficient in meeting the preferences of their populations, they must posses a fair degree of autonomy. H owever, it must al so be recognized that various groups must necessarily associate on some matters. In essence, the ideal institutional arrangement that would preserve ethnic autonomy and yet permit ethnic groups to be united for some purposes is a federal arrangement.

\section{Conditions $\mathrm{F}$ avoring $\mathrm{F}$ ederalism in Africa}

F ederal governments are fairly common and to a large extent function smoothly. Examples of federal governments include Australia, Canada, Germany, Switzerland, and the U nited States of America. The key characteristic of a federal system of government is the association of states or regions in which member states or regions retain a large measure of independence. F ederal governments adhere to the federal principle: The method of dividing powers so that the general and regional governments are each within a sphere, coordinate and independent. ${ }^{15}$

The proposed federalist option for African countries would be one where ethnic groups in various regions would establish their own regional governments. $E$ ach region would be independent in some spheres, which would be clearly stipulated in the federal constitution. These regions would then have elected representatives to the federal legislature as is the case with other federal governments. However,

${ }^{15}$ See Wheare (1947). F or detailed discussion of the federal principle, see Lemco (1991) and M acM ahon (1962). 
for African countries, emphasis is placed on how the local jurisdictions are drawn. ${ }^{16}$

There are many advantages of establishing federal systems of government in Africa. Federal systems permit policy experimentation and also facilitate the achievement of efficient outcomes due to interjurisdictional competition. ${ }^{17} \mathrm{H}$ owever, the primary advantage of establishing federalist institutions in Africa is that such is the only system of organizing collective activities that protects groups from oppression by others and also accommodates diversity. These outcomes reflect the fact that in a federal system power is decentralized and neither the general nor regional governments possess absolute power. ${ }^{18}$

In the unitary states of Africa, the central governments are frequently dominated by members of some group, race, tribe, or religion. As a result, chances are that in countries where there are heterogeneous groups, as is typical in Africa, some groups will be excluded from the ruling coalition. Given the unlimited powers to coerce possessed by unitary states, those governments often adopt discriminatory policies that oppress groups that are outside the ruling coalition. A federal system, with the guarantees afforded to regions in regard to their independence and the fact that the general government has limited powers, offers protection to all groups in the country.

E ven ethnic groups in the same countries tend to have significantly different social institutions. A main source of dissatisfaction by ethnic groups in Africa is that, more often than not, the policies adopted by the unitary governments fail to accommodate groups with widely varying preferences, customs, and norms. By attempting to unify otherwise diverse groups, unitary states fail to accommodate some groups. Thus, establishment of regional governments that possess a fair degree of autonomy allows individual groups to preserve their identity.

In additional to these benefits, several conditions exist in Africa that point to the appropriateness of federal systems of government. The high degree of ethnic heterogeneity in that continent and the fact that ethnic groups associate with particular territory have already

\footnotetext{
${ }^{16} \mathrm{~A}$ major issue in federal systems of governments is the allocation of functions between regional and the federal governments. We do not go into such details here. However, a well-functioning federal system is one that is highly decentralized so that most collective activity is left to the lower levels of government.

${ }^{17} \mathrm{~F}$ or a comprehensive treatment of the advantages of federal systems of government, see Breton (1980).

${ }^{18}$ The powers and responsibilities of federal governments vary. But, in general, they are clearly specified. The boundary of what the federal government should do must be clearly specified. The distribution of powers between regional and federal governments is crucial to the smooth functioning of the federal union.
} 
been noted. Both of these features present natural conditions for a federal system. In addition, religious heterogeneity is important in some countries. Nigeria and Sudan are good examples of countries where religious groups have clearly expressed their desire for autonomy. M ore often than not, leaders of unitary states establish policies that are clearly unsuitable to some groups. This is the primary reason why Christians in the south of Sudan have sought autonomy from the M uslim north. Such differences can be accommodated by establishing a federal system.

Another feature of African countries that would make federalism desirable is the geographical isolation of some communities. $E$ ven in an otherwise homogeneous nation, isolated communities develop distinct regional consciousness. Such consciousness makes the communities want to keep to themselves. When different communities in the same country develop such distinct regional awareness, they may all need to secure some degree of independence while uniting for some purposes. ${ }^{19}$ F urthermore, when communities are isolated from the rest of the country in a unitary state, they may rightfully feel that the central government is too remote from them and fails to serve them as well as it does other communities.

Another factor that favors the establishment of federal ist institutions in Africa is the size of the nations. Some of the countries are very large in terms of population and area. Nigeria has more than 100 million people, Ethiopia has a population of 54 million and Sudan has a population of 28 million. The geographical size of Sudan is onethird that of the entire United States; E thiopia is twice the size of Texas; M ozambique is twice the size of California, and Chad, with a population of only 5.2 million is three times the size of California. ${ }^{20}$ Somalia, which is relatively small compared with other African countries, is the size of Texas. Clearly, some of the African countries are excessively large, which makes it difficult for governments to serve local communities effectively.

Finally, many regions and communities in Africa had, at some time in the past, their own governments. Prior existence of "tribal" kingdoms, or chieftainships, means that there are already strong ties

\footnotetext{
${ }^{19}$ Such geographical isolation of communities played an important role in the creation of a federal system in Switzerland. Switzerland has a very rugged topography where mountains and valleys create small, isolated communities that are distinct and that have developed some degree of independence.

${ }^{20}$ Recently, some researchers have advanced the argument that the African states are themselves not optimal. In fact, this author believes that the map of Africa will radically change as democratic institutions mature and groups freely express their self-determination goals (Kimenyi 1997c, 1997d).
} 
that hold people in a particular region or community together. F urthermore, the fact that a government existed in the past implies that groups may want to regain their independence that they had before the formation of the unitary state. This has been evident in countries like U ganda, where previous kingdoms have continued to press for autonomy from the central government.

\section{Conclusion}

At the core of the analysis presented in this paper has been the relationship between ethnic heterogeneity and the costs and benefits of organizing collective activity. It has been suggested that ethnicity is an important feature of African countries and one that economizes on organizational costs. This suggests that the provision of public goods along ethnic lines has distinct efficiency characteristics. In particular, ethnic-based institutions have a comparative advantage in solving prisoner's dilemma problems.

A primary implication of the analysis is that the optimal institutional arrangement in nations characterized with high degrees of ethnic diversity is one that allows for the establishment of local "ethnic" jurisdictions. E ach of those jurisdictions should possess a fair degree of autonomy. Naturally, this suggests the establishment of multilevel governments. Thus, it appears that the most immediate institutional reform for Africa should be the establishment of federal systems of government.

Popularizing federalism with Africans is a challenging task. F ederalist proposals have been criticized by incumbent African leaders on the basis that such systems of government reinforce tribalism. The benefits associated with organizing along ethnic lines notwithstanding, the proposal outlined in this paper recommending the use of geoethnicity in determining appropriate regional units of collective choice is likely to be challenged as a form of "apartheid." F or federalism to be accepted as an ideal method of organizing society, it is necessary to emphasize the suitability of such a system particularly in creating a harmonious society.

Nonetheless, with the new democratization movements in Africa, there are signs of change. As a matter of fact, discussions by politicians and academics about the viability of federalism are going on in various countries. In K enya, for example, a debate has emerged that focuses on proposals to change the current institutional arrangements and instead establish a federal system with provincial governments. Likewise, E thiopia recently adopted a constitution that provides ethnic groups with a large measure of autonomy. 
The federalist proposal presented in this paper relies heavily on the fact that ethnic groups associate with specific territory and therefore calls for territorial federalism. However, territorial federalism may not solve some of the most serious ethnic rivalries in Africa. A good example is the case of the Hutu and Tusti in Rwanda and Burundi. These two groups share the same territories and no group has exclusive rights to a specific region. Territorial federalism is therefore not feasible in these countries. ${ }^{21}$

A possible solution to the ethnic rivalries in $\mathrm{R}$ wanda and Burundi may lie in the nonterritorial federalism proposed by Gordon Tullock (1994). N onterritorial federalism involves the establishment of competing governments in the same territory, and individuals have the option of selecting which governments to belong to. Such governments operate much like private clubs, so an individual could belong to various such governments. Thus, individuals residing in the same neighborhoods could actually belong to different nonterritorial states. While nonterritorial federal ism has some distinct advantages in dealing with ethnic conflicts, it is nevertheless a complicated institutional arrangement and not necessarily efficient from the standpoint of resource allocation. However, given the high costs associated with ethnic conflict in countries such as R wanda and Burundi, nonterritorial federalism should be given serious consideration.

\section{References}

Ayittey, G.B.N . (1991) Indigenous A frican I nstitutions. D obbs F erry: Transnational Publishers.

Ayittey, G.B.N. (1992) Africa Betrayed. New York: St. M artin's Press.

B reton, A. (1980) The D esign of F ederations. M ontreal: I nstitute for R esearch on Public Policy.

B reytenbach, W.J. (1976) "I nter-E thnic Conflict in Africa." In W .A. Veenhoven (ed.) Case Studies on Human Rights and Fundamental Freedoms, 311-31. The $\mathrm{H}$ ague: $\mathrm{M}$ artinus $\mathrm{N}$ ijhoff.

Brough, W.T., and Kimenyi, M.S. (1986) "On the Inefficient Extraction of Rents by Dictators." Public Choice 48: 37-48.

Buchanan, J.M . (1965) "An E conomic Theory of Clubs." E conomica 32: 1-14. Buchanan, J.M ., and Tullock, G. (1962) The Calculus of Consent. Ann Arbor: University of $\mathrm{M}$ ichigan Press.

Burke, F . (1991) Africa. Boston: Houghton M ifflin.

\footnotetext{
${ }^{21}$ The $\mathrm{H}$ utu-Tutsi problem is complex and may require quite complex solutions. Suggestions for dealing with the ethnic rivalries in these countries have included radical proposals such as designating one country for the Hutus and the other for the Tutsis. Other proposals have called for incorporating these countries into neighboring countries.
} 
Congleton, R.D . (1992) "E thnic Clubs, E thnic Conflict and the Rise of E thnic $\mathrm{N}$ ationalism." U npublished manuscript, Center for Study of Public Choice, George Mason University.

H obbes, T. ([1651] 1962) Leviathan. New York: Collier.

H orowitz, D . (1985) Ethnic Groups in Conflict. Berkeley: U niversity of California Press.

Kimenyi, M .S. (1987) "Bureaucratic Rents and Political Institutions." J ournal of Public Finance and Public Choice 3: 189-200.

Kimenyi, M .S. (1989) "Interest Groups, Transfer Seeking and D emocratization: Competition for the Benefits of Government Power M ay Explain African Political I nstability." American J ournal of E conomics and Sociology 48: 339-49.

Kimenyi, M .S. (1997a) Ethnic Diversity, Liberty and the State: The African Dilemma. Aldershot: E dward E Igar.

K imenyi, M.S. (1997b) "E thnic Rent-Seeking and Optimal Integration." Unpublished manuscript, D epartment of E conomics, University of Connecticut.

Kimenyi, M.S. (1997c) "Redrawing Africa's Borders: Logical Foundations for Consensual Units of Collective Choice." Unpublished manuscript, D epartment of E conomics, University of Connecticut.

K imenyi, M.S. (1997d) "Territorial Boundaries, Constitutions, and the D emand for N ew States." U npublished manuscript, D epartment of E conomics, U niversity of Connecticut.

Kimenyi, M.S., and M baku, J.M. (1993) "Rent-Seeking and Institutional Stability in Developing Countries." Public Choice 77: 385- 405.

L anda, J.T. (1994) Trust, Ethnicity and Identity. Ann Arbor: University of $\mathrm{M}$ ichigan Press.

Lemco, J. (1991) Political Stability in Federal Government. New York: Praeger.

L ewis, W.A. (1965) Politics in West Africa. New York: Oxford University Press.

L ittle, K. (1957) "The R ole of Voluntary Associations in W est African U rbanization." In P.L. Van den Berghe (ed.) Africa: Social Problems of Change and Conflict. San F rancisco: Chandler.

M acM ahon, A.W., ed. (1962) Federalism: M ature and E mergent. N ew York: Russell and Russell.

Mair, L. (1965) An Introduction to Social Anthropology. Oxford: Clarendon Press.

M baku, J.M., and Kimenyi, M.S. (1995) "D emocratization in Africa: The Continuing Struggle." Coexistence 32: 119-36.

Olson, M . (1965) The L ogic of C ollective Action. Cambridge: $\mathrm{H}$ arvard U niversity Press.

Roback, J. (1991 ) "Plural but E qual: Group I dentity and Voluntary I ntegration." Social Philosophy and Policy 8(2): 60-80.

Tullock, G. (1994) The New Federalist. Vancouver: F raser Institute.

Vaughan, J.H. (1986) "Population and Social Organization." In P. M artin and P. O'M eara (eds.) Africa. Bloomington: Indiana University Press.

Wheare, K.C. (1947) F ederal G overnment. L ondon: Oxford U niversity Press. Winchester, N .B. (1986) "Africa Politics Since Independence." In P. M artin and P. O'M eara (eds.) Africa. Bloomington: Indiana University Press. 